5

\title{
Konversi Lahan Pertanian Dan Perubahan Struktur Agraria \\ (Studi Kasus di Kelurahan Mulyaharaja, Kecamatan Bogor Selatan, Kota Bogor, Jawa Barat) ${ }^{1}$
}

Martua Sihaloho 2 , Arya Hadi Dharmawan ${ }^{3}$, Said Rusli ${ }^{4}$

\section{Ringkasan}

Tulisan ini merupakan hasil penelitian yang bertujuanmenganalisis konversi lahan pertanian dan perubahan struktur agraria di Kelurahan Mulyaharja. Strategi penelitian yang digunakan adalah pendekatan kualitati.Dampak konversi lahan pertanian di Kelurahan Muliahardja adalah ketimpangan struktur agraria lahan terhadap kehidupan masyarakat menyangkut perubahan pola penguasaan lahan, pola nafkah dan hubungan pola produksi. Ketimpangan struktur agraria berimplikasi terhadap kehidupan/kesejahteraan masyarakat. Tesis yang 'dibangun' adalah 'keadilan agraria'. Inti/gagasan tesis ini adalah perubahan struktur agraria yang menyebabkan tekanan sosial yang tidak merata, dimana kaum berpendapatan rendah/miskin adalah penderita utama atas hadirnya perubahan tersebut (fakta-fakta ketidak-adilan agraria) Harapan ke depan adalah proses pembangunan yang memperhatikan 'keadilan agraria' (pembangunan agraria yang memihak pada kaum miskin.

Katakunci: Konversi Lahan, struktur agraria and keadilan agraria

\section{Pendahuluan}

\subsection{Latar Belakang}

Pemanfaatan sumberdaya agraria merupakan salah satu upaya untuk memenuhi kebutuhan berbagai pihak yang terkait baik langsung maupun tidak langsung terhadap sumberdaya tersebut. Lahan atau spesifiknya tanah merupakan salah satu sumberdaya utama dalam melaksanakan program pembangunan. Dengan kata lain, ketersediaan tanah merupakan faktor penting dalam pembangunan khususnya pembangunan pertanian. Pembangunan pertanian dapat dipastikan selalu berorientasi pada peningkatan produksi dan kualitas hasil pertanian termasuk upaya diversifikasi jenis tanaman yang ditanam. Namun, ketersediaan tanah semakin berkurang seiring dengan pertambahan jumlah penduduk dan perubahan program atau rencana pembangunan dan juga perubahan kebijakan pihak yang terkait melalui upaya konversi lahan.

\footnotetext{
${ }^{1}$ Naskah ini merupakan revisi dari makalah Seminar Tesis Penulis Pertama.

${ }^{2}$ Lulusan Program Studi Sosiologi Pedesaan IPB Bogor, Peneliti Pada Pusat Kajian Agraria, LPPM-IPB

${ }^{3}$ Staf Pengajar Departemen Sosek IPB dan merupakan Ketua Komisi Pembimbing Tesis Penulis Pertama

${ }^{4}$ Staf Pengajar Departemen Sosek IPB dan merupakan Anggota Komisi Pembimbing Tesis Penulis Pertama
} 
Konversi lahan pertanian dapat 'diibaratkan' sebagai suatu perubahan sosial. Perubahan sosial terjadi pada suatu masyarakat seiring dengan perubahan ruang dan waktu. Konversi lahan tetap akan terjadi, paling tidak karena pertambahan penduduk secara natural untuk kebutuhan permukiman. Konversi juga terjadi dengan berubahnya desa-desa agraris menjadi desa-desa industri di pedesaan Jawa.

\subsection{Permasalahan}

Paling tidak lahan pertanian dapat dibedakan menjadi lahan produktif dan non-produktif. Fakta menunjukkan bahwa lahan pertanian produktif mengalami penurunan luas lahan. Implikasinya konversi lahan disatu sisi berupaya untuk meningkatkan 'nilai tanah' yang bertujuan meningkatkan pemanfaatan lahan oleh berbagai pihak baik untuk permukiman, industri dan untuk kepentingan lainnya dalam ruang dominasi negara (baca: pemerintah). Sementara disisi lain, konversi ini justru menyebabkan 'ketidakakses-an' masyarakat (lokal) terhadap sumberdaya agraria yang berimplikasi pada kesejahteraan masyarakat yang relatif 'kurang' dibandingkan pada kondisi awal.

Empat pertanyaan penelitian yang akan dijawab dalam studi ini adalah (1) Seberapa besar jumlah lahan pertanian yang terkonversi menjadi peruntukan lain, (2) Bagaimana implikasi perubahan atau konversi tersebut terhadap perubahan struktur agraria masyarakat menyangkut perubahan pola penguasaan lahan, pola nafkah dan hubungan pola produksi. dan (3) Bagaimana juga implikasinya ketimpangan struktur agraria terhadap kehidupan/kesejahteraan masyarakat dalam hal pilihan sumber mata pencaharian utama dan strategi lain selain mata pencaharian utama (di luar pertanian).

\subsection{Tujuan Penelitian}

Berdasarkan permasalahan di atas dapat dirumuskan tujuan penelitian yaitu, Untuk mengetahui dan menganalisis seberapa besar jumlah lahan pertanian yang terkonversi menjadi peruntukan lain, Untuk mengetahui dan memahami implikasi konversi tersebut terhadap perubahan struktur agraria menyangkut perubahan pola penguasaan lahan, pola nafkah dan hubungan pola produksi. Untuk mengetahui dan menganalisis implikasi ketimpangan struktur agraria terhadap kehidupan/kesejahteraan masyarakat' dalam hal pilihan sumber mata pencaharian utama dan strategi lain (mata pencaharian utama di luar pertanian). 


\section{Kerangka Pemikiran dan Hipotesa Pengarah}

\subsection{Kerangka Pemikiran}

Pertanian yang dimaksud dalam tulisan ini adalah pertanian dalam arti sempit yaitu pertanian usahatani untuk menghasilkan pangan dan hortikultura. Artinya, pertanian yang mencakup peternakan, perkebunan, perikanan dan kehutanan tidak termasuk dalam fokus penelitian ini. Dengan demikian konversi lahan yang dimaksud adalah konversi dari lahan pertanian ke konversi lahan non-pertanian atau konversi lahan non-pertanian ke konversi lahan pertanian yang dapat diketahui dari penurunan luas lahan pertanian dan meningkatnya peruntukkan untuk non-pertanian.

Batasan pada konversi lahan pertanian ini berimplikasi bahwa konversi lahan pertanian ke non-pertanian mencakup perubahan peruntukkan lahan pertanian kepada lahan peternakan, perkebunan, kehutanan, perikanan, industri, permukiman dan lain-lain. Faktor-faktor yang menyebabkan konversi lahan dapat dibagi menjadi dua kategori yaitu, (1) aras makro meliputi kebijakan pemerintah (kebijakan spasial dan agraria) dan pertumbuhan penduduk dan (2) aras mikro yang terdiri dari pola nafkah rumah tangga (struktur ekonomi rumah tangga) kesejahteraan rumah tangga (orientasi nilai ekonomi rumah tangga) strategi bertahan hidup rumah tangga (tindakan ekonomi rumah tangga).

Perubahan konversi lahan yang dianalisis adalah data tahun 1988 hingga tahun 2004. Konversi lahan telah menyebabkan perubahan pada berbagai aspek kehidupan masyarakat. Perubahan yang dimaksud berhubungan dengan perubahan struktur agraria, proses marginalisasi/kemiskinan dan pelaku konversi (warga masyarakat) 'tersubordinasi' oleh pihak pemanfaat konversi. Secara khusus implikasi dari perubahan struktur agraria adalah perubahan pola penguasaan agraria, pola nafkah, pola hubungan produksi dan perubahan orientasi nilai terhadap sumberdaya agraria. Perubahan tersebut tidak lepas dari faktor konversi sebagaimana dijelaskan di atas. Dalam konteks ini dapat disimpulkan bahwa keterkaitan antara faktor konversi dan dampak yang diakibatkannya menunjukkan 'ruang permasalahan agraria'. Dari ruang permasalahan agraria tersebut dapat diketahui bahwa konversi lahan telah meningkatkan keidak-adilan agraria.

Dengan demikian tesis yang ingin 'dibangun' adalah tesis keadilan agraria. Keadilan agraria yang dimaksud di sini adalah praktek-praktek pemanfaatan sumberdaya agraria oleh subyek agraria (pelaku konversi dan pemanfaat konversi) khususnya setelah alih hak milik (dari pelaku kepada pemanfaat) menyangkut redistribusi manfaat atau redistribusi penghasilan dari pemanfaat konversi kepada pelaku) yang dapat meningkatkan derajat kesejahteraan pemanfaat pelaku konversi. Tesis keadilan ini 'dibangun' karena realitas yang terjadi dalam konteks implikasi dari konversi lahan terhadap perubahan struktur agraria merupakan proses 'marginalisasi' atau kondisi ketidak-adilan. Demikian juga dengan realitas yang terjadi pada pasca konversi, proses 
konversi dan pasca konversi juga menunjukkan ketidak-adilan. Sehingga harapan ke depan pertanian dapat memperhatikan pentingnya 'keadilan agraria' yang pro-poor agrarian development.

Keadilan agraria yang ingin diwujudkan adalah meningkatnya kesejahteraan warga lokal/berkurangnya jumlah penduduk miskin (proses 'marginalisasi' terhenti), akses terhadap sumberdaya agraria (tanah) meningkat, kebijakan yang berpihak pada rakyat miskin, jaminan hidup rumah tangga warga yang bekerja di perumahan PT B dan perumahan PT C, warga lokal bebas dari 'belenggu' pemanfaat konversi (warga tidak hanya sebagai tamu di wilayahnya) dan penguatan kelembagaan lokal yang terkait dengan sumberdaya agraria (tanah). Secara ringkas kerangka pemikiran dalam studi ini dapat dilihat pada Gambar 1. 


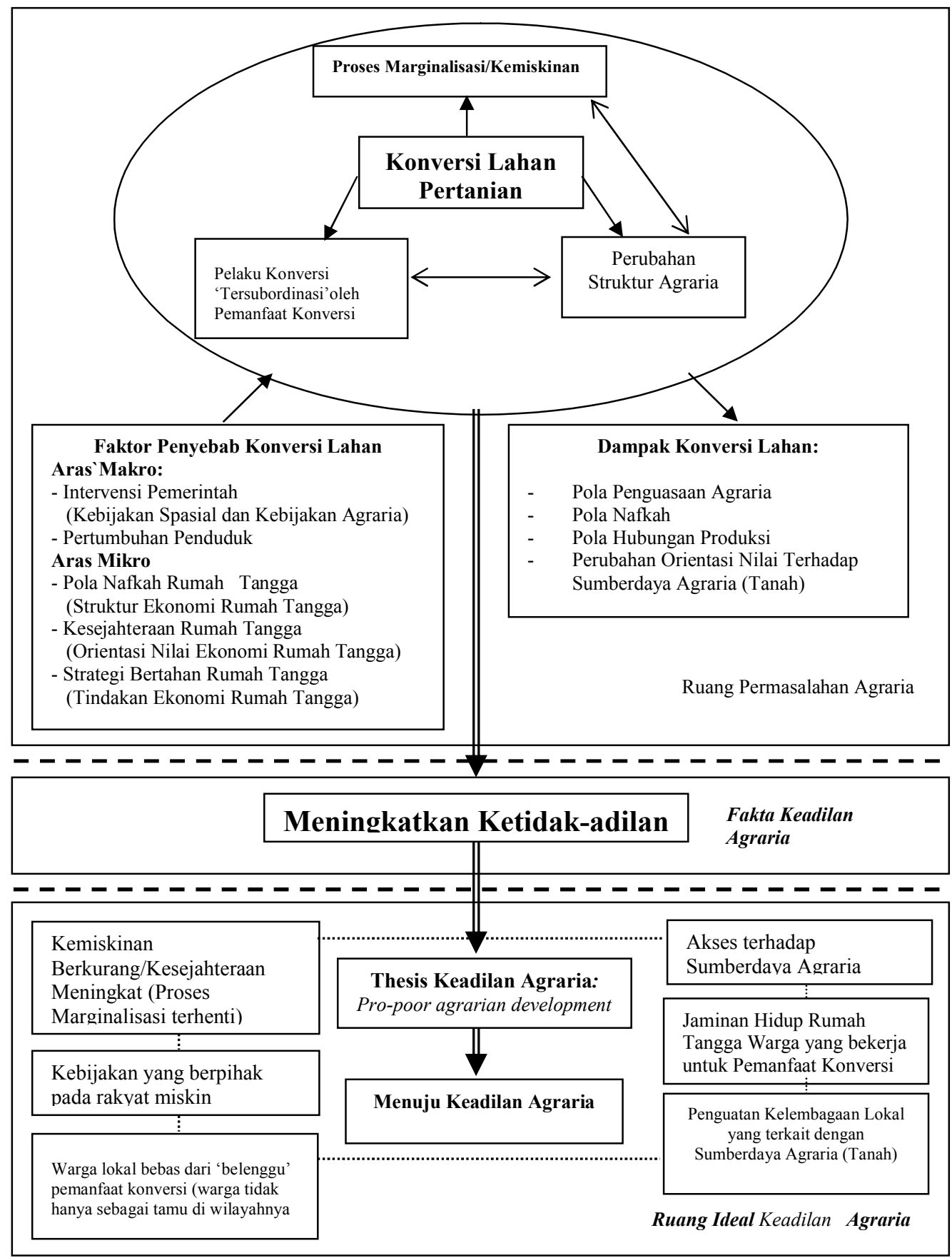

Keterang: $\longrightarrow \begin{aligned} & \text { : Hubungan Kausalitas } \\ & : \begin{array}{l}\text { Hubungan Keterkaitan di Dua Ruang } \\ \text { yang berbeda }\end{array}\end{aligned} \stackrel{\cdots \cdots}{\longleftrightarrow} \begin{aligned} & \text { : Keterkaitan Aspek Keadilan Agraria } \\ & : \text { Hubungan Saling Mempengaruhi }\end{aligned}$

Gambar 1. Bagan Alur Berpikir Konversi Lahan Pertanian dan Perubahan Struktur Agraria 


\subsection{Hipotesis Pengarah}

Tiga hipotesa pengarah yang menjadi 'acuan' dalam penelitian ini adalah:

1. Konversi lahan pertanian akan berimplikasi pada perubahan struktur agraria yang menghasilkan ketimpangan struktur agraria lahan terhadap kehidupan masyarakat menyangkut perubahan pola penguasaan lahan, pola nafkah dan pola hubungan produksi; termasuk perubahan pemaknaan (orientasi nilai) terhadap tanah.

2. Ketimpangan struktur agraria akan berimplikasi terhadap derajat kehidupan/ kesejahteraan masyarakat dan akan meningkatkan fakta ketidak-adilan agraria.

3. Keadilan agraria akan merupakan salah satu alternatif untuk mengatasi masalah ketidak-adilan agraria yang ditunjukkan oleh aspek-aspek keadilan agraria.

\section{Metode Penelitian}

\subsection{Tempat dan Waktu Penelitian}

Pilihan lokasi penelitian ini dilakukan secara sengaja yaitu di Kelurahan Mulyaharja, Kotamadya Bogor, Jawa Barat. Beberapa alasan pemilihan lokasi adalah (1) Kajian atas lokasi penelitian dapat menjawab permasalahan pokok studi ini secara lebih spesifik, (2) Lokasi merupakan salah satu daerah 'pinggiran' kota metropolitan dengan dinamika masalah pembangunan yang relatif 'tersentuh' bagi berbagai pihak. Penelitian ini dilaksanakan pada bulan April-Juli 2004.

\subsection{Strategi Penelitian}

Strategi penelitian studi ini adalah pendekatan kualitatif. Penelitian ini juga menggunakan studi kasus, yaitu suatu proses pengkajian dan pengumpulan data secara mendalam dan detail terhadap seputar kejadian khusus sebagai 'kasus' yang dipilih (Neuman, 1994). Kasus yang diambil dalam studi ini adalah menyangkut pilihan lokasi yang sesunguhnya juga dipilih secara sengaja. Yin (1996) juga mengemukakan bahwa studi kasus adalah studi aras mikro yang bersifat multi-metode, dengan titik berat pada metode-metode nonsurvei.

Penelitian ini memadukan metode pengamatan, wawancara mendalam, (indepth interview), studi/analisis data dokumen/sekunder. Informasi diperoleh dari responden, tokoh informan kunci (key informant), diskusi kelompok dan juga kajian dokumen atau data sekunder yang relevan.

\subsection{Prosedur Penelitian dan Analisis Data}

Data yang dianalisis dalam studi ini adalah data sekunder dan data primer. Data sekunder merupakan dokumen atau data yang diperoleh dari laporan 
studi, data statistik dari kantor BPS, data dari Kecamatan Bogor Selatan dan Kotamadya Bogor. Data kualitatif dalam studi ini diperoleh dari responden dan informan baik dari pihak kecamatan, kelurahan, kelompok tani, petani, Dinas Pertanian dan Tanaman Pangan Kota Bogor, pelaku konversi dan pihak pemanfaat konversi lahan.

Dua jenis data di atas dianalisis, dikaji dan dirumuskan menjadi sejumlah rangkaian argumentasi yang didukung oleh fakta empiris di lapangan. Data kualitatif dianalisis sejak peneliti berada di lapangan melalui tahapan reduksis data (menyunting data dan melihat kelengkapan dan keabsahan data, menganalisis, menuliskan informasi-informasi lain yang relevan dilapangan). Langkah kedua adalah menyajikan data hingga memungkinkan dilakukan menarik butir pokok hingga memperoleh kesimpulan utama. Hasil atau kesimpulan didiskusikan ulang dengan tineliti atau responden/informan.

\section{Peta Konversi Lahan di Kelurahan Mulyaharja}

\subsection{Konversi Lahan Pertanian Kelurahan Mulyaharja}

Lahan pertanian yang dipahami dalam konteks ini adalah lahan sawah dan lahan ladang yang umumnya produktif dimanfaatkan untuk tanaman padi, hortikultura dan juga tanaman tahunan lainnya. Konversi lahan terjadi pada lahan pertanian menjadi wilayah permukiman (Tabel 2). Hal ini ditunjukkan peningkatan luas lahan permukiman dan berkurangnya luas lahan pertanian dan kebun campuran, yang juga terkonversi menjadi wilayah permukiman. 
Tabel 1. Sebaran Penggunaaan Tanah Sebelum dan Sesudah Masuknya Pemilik Modal (Perusahaan) serta Menurut Rencana Tata Ruang Wilayah (RTRW)

\begin{tabular}{|c|c|c|c|c|}
\hline \multirow[b]{2}{*}{ No } & \multirow[b]{2}{*}{ Jenis Pekarangan } & \multicolumn{3}{|c|}{ Luas Lahan (Ha) dalam Persentase (\%) } \\
\hline & & $\begin{array}{c}\text { Sebelum } \\
\text { Masuknya } \\
\text { Pemilik Modal } \\
(1988)\end{array}$ & $\begin{array}{c}\text { Sesudah } \\
\text { Masuknya } \\
\text { Pemilik Modal } \\
(2002 / 2004)\end{array}$ & $\begin{array}{c}\text { Menurut } \\
\text { RTRW } \\
(2005)\end{array}$ \\
\hline 1. & Permukiman/Perumahan & $92,00(19,28)$ & $\left.152,92^{\star}\right)(42,05)$ & $\begin{array}{l}269,42 \\
(56,47)\end{array}$ \\
\hline 2. & Pertanian & $274,88(57,62)$ & $\left.243,00^{\star \star}\right)(50,94)$ & $\begin{array}{l}117,50 \\
(24,63)\end{array}$ \\
\hline 3. & Kebun Campuran & $98,00(20,54)$ & $70,88(14,86)$ & $\begin{array}{r}63,88 \\
(13,39)\end{array}$ \\
\hline 4. & Sungai & $9,00(1,88)$ & $9,00(1,88)$ & $9,00(1,88)$ \\
\hline 5. & Industri & - & - & - \\
\hline 6. & Perkantoran & $0,22(0,04)$ & $0,22(0,04)$ & $1,20(0,25)$ \\
\hline 7. & Perdagangan & - & - & $6,00(1,26)$ \\
\hline 8. & $\begin{array}{l}\text { Taman dan Lap. } \\
\text { Olahraga }\end{array}$ & - & - & $4,00(0,83)$ \\
\hline 9. & Kuburan & $4,00(0,83)$ & $4,00(0,83)$ & $4,00(0,83)$ \\
\hline 10. & Total & $477,005(100)$ & $477,005(100)$ & $\begin{array}{r}477,005 \\
(100)\end{array}$ \\
\hline
\end{tabular}

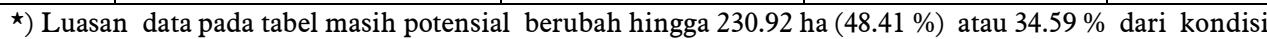
2002-2004.

$\star \star)$ Luasan data pada tabel masih potensial berubah hingga 165 ha $(34.59 \%)$ atau $51.31 \%$ dari kondisi 2002-2004.

Mengacu pada kepadatan agraris, konversi lahan yang terjadi masa lalu menyebabkan kepadatan agraris di Kelurahan Mulyaharja bertambah dari 1.74 (415/238.05 ha) menjadi 2.25 (415/184). Angka tersebut makin bertambah dengan pertambahan jumlah petani dan buruh tani menjadi $3.72(685 / 184)$. Kepadatan agraris mengalami peningkatan baik karena pertambahan jumlah petani maupun karena berkurangnya akses pada sumberdaya agraria tanah. Implikasi dari berkurangnya akses terhadap tanah adalah semakin berkurangnya ketersediaan lahan bagi petani dan buruh tani serta dapat mengarah pada perubahan pola nafkah agraria dari pertanian ke non pertanian, pola hubungan agraria yang akan dijelaskan pada sub-bab selanjutnya.

\subsection{Faktor-faktor Pendorong terjadinya Konversi Lahan Pertanian}

Konversi lahan yang akan dikaji pada sub-bab ini adalah perubahan hak atas tanah dari pemilik awal kepada pemilik sekarang dan bagaimana perubahan pengelolaan dan pemanfaatan lahan awal dengan sekarang dan rencana yang 
akan datang. Faktor-faktor Konversi lahan pertanian yang dapat diidentifikasi adalah pertumbuhan penduduk, keterdesakan ekonomi, faktor luar, intervensi pihak swasta dan intervensi pemerintah.

Konversi lahan di atas diakibatkan oleh beberapa faktor dan yaitu Pertumbuhan Penduduk, yang kebutuhan lahan untuk permukiman yang juga makin meningkat, Keterdesakan Ekonomi, yang mendorong motivasi untuk berubah; Faktor luar, yang mendorong 'motivasi mengikuti' bagi warga Kelurahan Mulyaharja untuk menjual tanahnya; Investasi Pihak Swasta, yang menawarkan membeli tanah dan tidak jarang disertai dengan 'paksaan' dan 'iming-iming' pekerjaan; Proses Alih Hak Milik Atas Tanah, yang menyebabkan perubahan orientasi pemanfaatan asset, dan Intervensi Pemerintah, yang berusaha mengikuti rencana yang telah dibuat serta Proses Pengadaan Tanah, yang secara administratif mengikuti aturan, tetapi mendahulukan pihak yang relatif lebih dominan.

\section{Konversi Lahan Pertanian dan Perubahan Struktur Agraria}

Dampak konversi dapat dilihat pada berbagai aspek. Pada bagian ini secara spesifik akan diuraikan perubahan struktur agraria lokal dalam hal pola penguasaan sumberdaya agraria, pola penggunaan tanah dan pola hubungan agraria dan pola nafkah agraria.

Pola Penguasaan Sumberdaya Agraria Tanah. Pola penguasaan tanah dapat diketahui pertama dari pemilikan lahan dan bagaimana tanah tersebut diakses oleh orang lain. Penguasaan dapat dibagai menjadi dua yaitu pemilik sekaligus penggarap, pemilik yang mempercayakan kepada penggarap. Pemilik penggarap umumnya dilakukan oleh petani berlahan sempit karena ketergantungan ekonomi dan kebutuhan akan rumah tangga maka pemilik sekaligus menggarap lahannya dengan menggunakan tenaga kerja keluarga dan atau memanfaatkan tenaga buruh tani. Kedua, pemilik yang mempercayakan kepada penggarap dengan system bagi hasil merupakan pola yang khas terjadi di Indonesia sejak tahun 1931 (Sceltema, 1985).

Pola Penggunaan Tanah. Pola penggunaan sumberdaya agraria tanah dapat dilihat dari bagaimana masyarakat dan pihak-pihak lain memanfaatkan sumberdaya agraria tersebut. Masyarakat memandang tanah sebagai bagian yang terpenting dalam kehidupannya karena pemanfaatannya bertujuan untuk memenuhi kebutuhan dasar. Umumnya petani memanfaatkan lahan sawah lebih dari satu kali tanam setahun (2-3 kali tanam setahun atau intensitas pertaniannya mencapai 200-300 \%). Demikian juga dengan lahan kering, jika hanya ditanami sayuran dan ubi jalar, dapat ditanami 2-5 kali tanam setahun. Berbeda jika menanam tanaman tahunan seperti pisang dan ubi kayu.

Pola Hubungan Agraria. Pola penggunaan tanah berkaitan dengan sarana dan prasarana di tingkat kelurahan selain untuk pertanian dan perladangan masyarakat baik dari Kelurahan Mulyaharja maupun dari desa atau kelurahan 
lainnya. Tanah di kelurahan sebagian besar sudah dimiliki oleh orang luar kelurahan dan PT.

Masyarakat setempat yang memiliki tanah memanfaatkan lahan dapat dibagi menjadi tiga kategori yaitu (1) Masyarakat yang memiliki lahan luas dan menggarapkan sawahnya kepada warga lain; pemilik tanah ini menerapkan sistem sewa ataupun bagi hasil seperti sistem adalah maro dan mertelu, (2) Pemilik lahan sempit yang melakukan pekerjaan usahatani dengan tenaga kerja keluarga dan (3) Pemilik lahan yang melakukan usahatani sendiri tetapi banyak memanfaatkan tenaga kerja buruh tani.

Pola Nafkah Agraria. Pola nafkah agraria dikaji berdasarkan sistem mata pencaharian masyarakat dari hasil-hasil produksi pertanian dibandingkan dengan hasil dari non-pertanian. Pada kasus di Kelurahan Mulyaharja, pola nafkah agraria masyarakat setempat adalah mata pencaharian dari hasil pertanian dan non-pertanian. Umumnya masyarakat Kelurahan Mulyaharja bermata pencaharian dari hasil pertanian yaitu sebagai petani dan buruh tani. Sedangkan dari sektor non-pertanian yaitu wiraswasta 'bengkel' sepatu-sendal, dagang/warung, tukang ojek, supir angkot, dan lain-lain.

\section{Pola Konversi Lahan di Kelurahan Mulyaharja}

Konversi lahan sebagaimana telah dijelaskan pada bab sebelumnya merupakan konversi dari peruntukkan lahan pertanian dan sawah menjadi permukiman dan atau peternakan (lihat Tabel 10). Berdasarkan faktor pokok konversi, pelaku, pemanfaat dan prosesrnya, konversi lahan di Kelurahan Mulyaharja dapat dibedakan menjadi 9 (sembilan) pola atau tipologi.

\section{a. Konversi Gradual-Berpola Sporadis}

Pola konversi ini diakibatkan oleh dua faktor penggerak utama yaitu lahan yang tidak/kurang produktif (bermanfaat secara ekonomi) dan 'keterdesakan ekonomi pelaku konversi. Sebagai petani, warga membutuhkan lahan yang produktif. Setelah menjual tanahnya, warga membeli tanah lain dan ada juga yang tidak dapat membeli lagi karena uang hasil penjualan tanah dimanfaatkan oleh keluarga untuk kebutuhan yang mendesak.

\section{b. Konversi Sistematik berpola 'enclave'}

Konversi tanah berpola 'enclave' yang dimaksud adalah sehamparan tanah yang terkonversi secara serentak. Pemilik tanah dapat terdiri dari beberapa orang. Pola konversi ini juga terjadi di Kelurahan Mulyaharja (selanjutnya disingkat KM). Hasil wawancara dengan Ketua RT 01/RW 08 dapat diketahui bahwa lahan Perumahan PT B merupakan lahan yang dimiliki oleh orang luar KM (70 \%) dan sisanya (30\%) dimiliki oleh orang luar desa. Luas lahan yang terkonversi dalam pola ini adalah 3 ha. Tanah tersebut kurang produktif dan hasil pemanfaatannya juga diakses oleh orang luar KM. Kini, setelah lahan dialihfungsikan menjadi permukiman, nilai manfaatnya dapat dirasakan oleh masyarakat KM. 


\section{c. Konversi Lahan sebagai Respon Atas Pertumbuhan Penduduk (Population growth driven land conversion).}

Konversi tidak dapat dihindari dalam suatu wilayah tertentu karena lahan akan terkonversi untuk memenuhi kebutuhan tempat tinggal. Pertumbuhan penduduk baik secara alami (natural) maupun mapun karena migrasi masuk lebih besar dari keluar dari tahun 1990-2003 di KM antara 2-5 persen per tahun. Kebutuhan tempat tinggal akibat pertambahan penduduk, mengakibatkan lahan-lahan terkonversi. Konversi yang diakibatkan oleh faktor penggerak utama pertumbuhan penduduk disebut dengan konversi adaptasi demografi.

\section{d. Konversi yang disebabkan oleh Masalah Sosial (social problem driven land conversion)}

Keterdesakan ekonomi dan perubahan kesejahteraan adalah dua faktor utama penggerak melakukan konversi lahan. Karena desakan ekonomi, lahan di jual kepada pendatang di KM. Ada juga pelaku yang pindah ke daerah perkampungan (masih di KM). Setelah ekonomi makin baik, tanah di perkampungan KM kembali di jual. Alasan menjual adalah perubahan kesejahteraan; ingin menikmati yang relatif lebih baik semisal fasilitas listrik, air, akses ke jalan, dekat ke sekolah untuk anak-anak, dekat ke tempat pekerjaan dan lain-lain.

Pada kasus keluarga ANI, selain menginginkan perubahan, keluarga ini menginginkan kedekatan dengan pinggiran jalan. Alasan ini berkaitan dengan pekerjaan keluarga kasus yaitu sebagai petani dan pedagang.

'Suami saya (Alm RS) mengajak keluarga kami pindah karena ia ingin kami dekat ke jalan. Dia bekerja sebagai petani dan juga pedagang. Hasil pertanian kami dan hasil pertanian warga Pabuaran dibeli dan di jual di Pasar Bogor. Tanah yang dijual seluas 0,75 ha. Hasil penjualan digunakan untuk membeli tanah di $R W 08$ seluas 0,5 ha dan membangun rumah. Tanah yang dulu sama subur dengan yang disini. Anak-anak saya juga sangat senang kami pindah karena mereka dapat melanjutkan sekolah hingga SLTA. Anak pertama sekolah SLTA (STM), sedang anak kedua hanya SLTP. Rumah yang sekarang sudah dibangun tiga tahap. Tahapan ketiga memasang lantai keramik.

\section{e. Konversi "Tanpa Beban"}

Satu faktor pengegerak utama dari pola konversi tanpa beban ini adalah keinginan untuk mengubah nasib hidup yang lebih baik dari keadaan saat ini dan ingin ke luar dari kampung dan atau kelurahan. Khusus untuk penduduk kampung Pabuaran, sekitar $30 \%$ warga pindah ke luar kampung. Pola konversi ini terkait dengan pola konversi masalah sosial dalam hal keinginan untuk berubah. Namun pola konversi tanpa beban ini lebih pada warga yang menjual tanahnya dan sekaligus ke luar dari sektor pertanian ke non-pertanian. Hal lain yang menyebabkan pola konversi 'tanpa beban' ini adalah kondisi sarana dan 
prasarana di wilayah perkampungan. Dengan demkian, pada aras rumah tangga terjadi perubahan asset tanah ke pihak luar desa.

\section{f. Konversi Adaptasi Agraris}

Pola konversi adaptasi agraris terjadi karena keterdesakan ekonomi dan keinginan untuk berubah dari warga KM. Dikatakan berpola adaptasi agraris jika warga yang memiliki tanah yang relatif kurang produktif (kelas 2-5) ingin meningkatkan hasil pertaniannya dengan cara menjual tanah yang kurang produktif dan membeli tanah yang relatif rebih bagus (kelas 1-2; paling tidak ada perubahan kualitas).

Hasil penjualan tanah tidak selalu dapat menggantikan seluasan tanah yang dijual. Dengan kata lain, lahan yang dibeli dapat lebih sempit dengan kualitas yang lebih baik, atau lebih luas, tetapi lebih jauh dari perkampungan. Perbedaan diakibatkan perbedaan kualitas tanah dan letak dari perkampungan/permukiman.

\section{g. Konversi Multi Bentuk atau Tanpa Bentuk/Pola}

Pola konversi multi bentuk ini merupakan konversi yang diakibatkan berbagai faktor. Namun, secara khusus faktor yang dimaksud adalah faktor peruntukan untuk perkantoran, sekolah, koperasi, perdagangan; termasuk sistem waris yang tidak spesifik dijelaskan dalam konversi adaptasi demografi. Secara ringkas, tujuh pola konversi yang telah dijelaskan di atas dapat di lihat pada Tabel 2.

Tabel 2. Pola Konversi Lahan di Kelurahan Mulyaharja Tahun 2004

\begin{tabular}{|c|c|c|c|c|c|}
\hline $\begin{array}{l}\text { Pola } \\
\text { Konversi } \\
\text { Lahan }\end{array}$ & $\begin{array}{c}\text { Faktor Penggerak } \\
\text { Utama (driving force) }\end{array}$ & $\begin{array}{c}\text { Pelaku } \\
\text { Konversi } \\
\text { Lahan }\end{array}$ & Pemanfaat & Proses Konversi & $\begin{array}{c}\text { Ketera- } \\
\text { ngan }\end{array}$ \\
\hline $\begin{array}{l}\text { Konversi } \\
\text { Gradual- } \\
\text { berpola } \\
\text { sporadis }\end{array}$ & $\begin{array}{l}\text { Lahan tidak } \\
\text { produktif lagi } \\
\text { (bermanfaat) dan } \\
\text { Keterdesakan } \\
\text { ekonomi }\end{array}$ & $\begin{array}{l}\text { Warga } \\
\text { KM dan } \\
\text { Luar } \\
\text { KM }\end{array}$ & $\begin{array}{l}\text { Warga KM, } \\
\text { Luar KM } \\
\text { dan pihak } \\
\text { PT }\end{array}$ & $\begin{array}{l}\text { Karena lahan makin tidak } \\
\text { produktif, maka lahan dijual } \\
\text { pelaku kepada pihak } \\
\text { pemanfaat }\end{array}$ & $\begin{array}{l}\text { Ada } \\
\text { (Minor) }\end{array}$ \\
\hline $\begin{array}{l}\text { Konversi } \\
\text { Sistematik } \\
\text { berpola } \\
\text { 'enclave' }\end{array}$ & $\begin{array}{l}\text { Tawaran pihak } \\
\text { pemodal dan } \\
\text { Keinginan alih } \\
\text { fungsi lahan }\end{array}$ & $\begin{array}{l}\text { Warga } \\
\text { KM dan } \\
\text { Luar } \\
\text { KM }\end{array}$ & $\begin{array}{l}\text { Warga, } \\
\text { Pihak } \\
\text { Swasta dan } \\
\text { atau } \\
\text { Pemerintah }\end{array}$ & $\begin{array}{lcr}\text { Karena progam } & \text { dan atau } \\
\text { tawaran dari } & \text { pemanfaat } \\
\text { lahan } & \text { dijual } & \text { secara } \\
\text { menyeluruh } & \end{array}$ & $\begin{array}{l}\text { Ada } \\
\text { (Domi- } \\
\text { nan) }\end{array}$ \\
\hline $\begin{array}{l}\text { Konversi } \\
\text { Adaptasi } \\
\text { Demografi } \\
\text { (Population } \\
\text { growth driven } \\
\text { land } \\
\text { conversion) }\end{array}$ & $\begin{array}{l}\text { Kebutuhan tempat } \\
\text { tinggal dan } \\
\text { Pertambahan } \\
\text { penduduk baik } \\
\text { karena pertambahan } \\
\text { penduduk alami } \\
\text { maupun karena } \\
\text { migrasi masuk lebih } \\
\text { besar dari keluar }\end{array}$ & $\begin{array}{l}\text { Warga } \\
\text { KM dan } \\
\text { Luar } \\
\text { KM }\end{array}$ & $\begin{array}{l}\text { Warga Luar } \\
\text { KM }\end{array}$ & $\begin{array}{l}\text { Baik lahan yang produktif } \\
\text { dan non-produktif dijual } \\
\text { dan dibangun rumah karena } \\
\text { pertambahan penduduk di } \\
\text { KM dari luar KM. Sebagai } \\
\text { respons atas perkembangan } \\
\text { demografi di suatu kawasan } \\
\text { misalnya kampung }(\mathrm{RW})\end{array}$ & $\begin{array}{l}\text { Ada } \\
\text { (Minor) }\end{array}$ \\
\hline
\end{tabular}




\begin{tabular}{|c|c|c|c|c|c|}
\hline $\begin{array}{l}\text { Konversi } \\
\text { Masalah } \\
\text { Sosial (Social } \\
\text { Problem } \\
\text { driven land } \\
\text { conversion) }\end{array}$ & $\begin{array}{l}\text { Keterdesakan } \\
\text { ekonomi dan } \\
\text { Perubahan } \\
\text { kesejahteraan }\end{array}$ & $\begin{array}{l}\text { Warga } \\
\text { KM }\end{array}$ & Warga KM & $\begin{array}{l}\text { Dulu, karena desakan } \\
\text { ekonomi, lahan di jual } \\
\text { kepada pendatang di KM. } \\
\text { Pelaku pindah ke daerah } \\
\text { perkampungan KM (masih } \\
\text { di KM). Setelah ekonomi } \\
\text { makin baik, perkampungan } \\
\text { KM kembali di jual. Alasan } \\
\text { menjual adalah perubahan } \\
\text { kesejahteraan; ingin } \\
\text { menikmati yang relatif lebih } \\
\text { baik semisal fasiltas listrik, } \\
\text { air, telepon, kesehatan dan } \\
\text { lain-lain di pinggiran jalan }\end{array}$ & $\begin{array}{l}\text { Ada } \\
\text { (Minor) } \\
\text { 'Unik' } \\
\text { Spesifik } \\
\text { Lokal }\end{array}$ \\
\hline $\begin{array}{l}\text { Konversi } \\
\text { Tanpa Beban }\end{array}$ & $\begin{array}{l}\text { Keinginan untuk } \\
\text { berubah dan ingin } \\
\text { ke luar dari } \\
\text { kampung dan atau } \\
\text { kelurahan }\end{array}$ & $\begin{array}{l}\text { Warga } \\
\text { KM dan } \\
\text { Luar } \\
\text { KM }\end{array}$ & $\begin{array}{l}\text { Warga KM, } \\
\text { Luar KM } \\
\text { dan Pihak } \\
\text { Investor }\end{array}$ & $\begin{array}{l}\text { Lahan yang dimiliki Pelaku } \\
\text { dijual dan pindah ke Luar } \\
\text { KM. }\end{array}$ & Ada \\
\hline $\begin{array}{l}\text { Konversi } \\
\text { Adaptasi } \\
\text { Agraris }\end{array}$ & $\begin{array}{l}\text { Keterdesakan } \\
\text { ekonomi dan } \\
\text { keinginan untuk } \\
\text { berubah }\end{array}$ & $\begin{array}{l}\text { Warga } \\
\text { KM dan } \\
\text { Luar } \\
\text { KM }\end{array}$ & $\begin{array}{l}\text { Warga KM, } \\
\text { Luar KM } \\
\text { dan Pihak } \\
\text { Investor }\end{array}$ & $\begin{array}{l}\text { Pelaku menginginkan } \\
\text { perubahan dilakukan } \\
\text { dengan menjual tanah yang } \\
\text { kurang produktif untuk } \\
\text { mendapatkan tanah yang } \\
\text { produktif. }\end{array}$ & $\begin{array}{l}\text { Ada } \\
\text { (Minor), } \\
\text { 'Unik'/ } \\
\text { Spesifik } \\
\text { Lokal }\end{array}$ \\
\hline $\begin{array}{l}\text { Konversi } \\
\text { Multi } \\
\text { Bentuk atau } \\
\text { Tanpa } \\
\text { Bentuk/Pola }\end{array}$ & $\begin{array}{l}\text { Semua faktor; } \\
\text { termasuk kebutuhan } \\
\text { pihak tertentu }\end{array}$ & $\begin{array}{l}\text { Warga } \\
\text { KM dan } \\
\text { Luar } \\
\text { KM }\end{array}$ & $\begin{array}{l}\text { Warga KM, } \\
\text { Luar KM } \\
\text { dan Pihak } \\
\text { Investor }\end{array}$ & $\begin{array}{l}\text { Satu peruntukan menjadi } \\
\text { satu peruntukan lain atau } \\
\text { lebih, dilakukan kapan saja } \\
\text { dalam hal ini termasuk } \\
\text { perubahan dalam skala kecil } \\
\text { mencakup lahan sawah, } \\
\text { ladang, kebun campuran, } \\
\text { maupun perumahan. }\end{array}$ & $\begin{array}{l}\text { Ada } \\
\text { (Minor) }\end{array}$ \\
\hline
\end{tabular}

Sumber: Data Primer 2004 (diolah)

Pada Tabel 2 di atas ditunjukkan pola-pola konversi lahan yang terjadi di Kelurahan Mulyaharja (KM). Sebagaimana telah dijelaskan pada bab sebelumnya, bahwa konversi lahan merupakan fakta yang terjadi di wilayah kabupaten/kota baik di baik di pedesaan maupun perkotaan, di Jawa maupun di luar Jawa. Pola konversi di atas juga menggambarkan pola yang 'unik' atau spesifik lokal terjadi di Kelurahan Mulyaharja, khususnya 'pola konversi adaptasi agraris' dan 'pola konversi masalah sosial'.

\section{Perubahan Pemaknaan (Orientasi Nilai) dan Fungsi Tanah di Kelurahan Mulyaharja}

Berbicara mengenai nilai dan fungsi, maka satu hal yang terpikirkan adalah konsep nilai dan fungsi. Nilai yang dimaksud di sini adalah hal yang berhubungan dengan baik-buruk. Selanjutnya fungsi mengacu pada manfaat tanah bagi warga setempat atau bagi pemanfaat. Dalam konteks nilai dan fungsi tanah dapat dipahami bagaimana warga memaknai tanah bagi kehidupan.

Sejak adanya kehidupan di dunia ini, tanah merupakan salah satu sumberdaya yang penting bagi mahkluk hidup. Tanah merupakan salah satu bagian dari 
ekosistem, tempat mahluk hidup 'berdiam, bertumbuh dan berkembang'. Demikianlah tanah adalah bagian yang tidak dapat dipisahkan dalam kehidupan mahluk hidup. Pada awalnya, tanah umumnya dimanfaatkan untuk keperluan produksi (misalnya bertani, memelihara ikan, ternak, dan lain-lain) dibandingkan untuk keperluan reproduksi seperti tempat tinggal, tempat mandi, tempat bereproduksi dan lain-lain. Hal ini berhubungan dengan keberadaan masyarakat Indonesia sebagai masyarakat agraris yang hidup dan bermatapencaharian dari hasil pertanian.

Seiring dengan perubahan waktu, masyarakat juga mengalami perubahan dalam berbagai aspek baik ekonomi, sosial-budaya, pandangan dan pemamfaatan terhadap sumberdaya alam. Implikasi dari perubahan gagasan dan pandangan masyarakat terhadap sumberdaya alam ini adalah perubahan tindakan manusia manusia dalam hal pemanfaatannya yang juga diikuti perubahan sistem teknologi (peralatan), yang juga digunakan untuk pemanfaatan dan penggunaannya. Hal ini dapat dilihat dari perubahan pemanfaatan tanah tidak lagi didominasi praktek-praktek pemanfaatan dalam hal meningkatkan fungsi produksi melainkan terjadi pergeseran ke arah pemanfaatan tanah untuk fungsi reproduksi. Misalnya perubahan pemanfaatan tanah dari pertanian menjadi perumahan.

Perubahan fungsi tanah sebagaimana disebut di atas dapat dilihat dari keberadaan rumah-rumah permukiman penduduk, perumahan PT B dan perumahan PT C. Adanya perumahan ini menunjukkan perubahan yang relatif besar karena terjadi alih fungsi lahan dalam jumlah luas dari pemanfaatan fungsi produksi untuk pertanian menjadi pemanfaatan untuk fungsi reproduksi. Perubahan di KM ini menunjukkan perubahan pemaknaan tanah dimana tanah pada dasarnya memiliki arti penting bagi masyarakat setempat. Namun, karena faktor-faktor konversi sebagaimana telah dijelaskan pada subbab sebelumnya, warga KM menjual tanahnya dan pada akhirnya dimanfaatkan untuk fungsi-fungsi reproduksi baik oleh warga KM maupun oleh 'pemanfaat konversi'.

\section{Pasca Konversi Lahan: Menuju Keadilan Agraria}

Pada bagian ini penulis ingin menegaskan bahwa dipandang perlu upaya-upaya meminimalkan konversi lahan pertanian. Upaya ini dilakukan mengingat ketergantungan masyarakat terhadap lahan masih sangat tinggi khususnya masyarakat yang bermatapencaharian dari sektor pertanian baik sebagai petani, buruh tani maupun pedagang hasil pertanian.

Perubahan lain yang terjadi di sektor pertanian adalah berkurangnya peluang berusaha di sektor pertanian seiring dengan perubahan petani pemilik menjadi petani penggarap dan petani penggarap menjadi buruh tani dan sebagian buruh tani tidak dapat bekerja di sektor pertanian. Pilihan pekerjaan lain bagi mereka adalah bekerja di sektor non-pertanian dengan kebutuhan tingkat kealihan yang relatif rendah (relatif sama dengan petani/buruh tani) semisal bekerja di 'bengkel sepatu', tukang ojek, buka warung dan lain-lain. Dengan demikian 
konversi lahan menyebabkan makin sempitnya lahan pertanian dan implikasinya adalah makin sulitnya buruh tani mendapatkan pekerjaan.

Bentuk perubahan penting yang terjadi di Kelurahan Mulyaharja adalah mencakup aspek sosiologis, ekonomis, ekologis, politis dan sosial budaya. Perubahan struktur agraria yang terjadi berimplikasi pada menguatnya proses 'marginalisasi' yang ditunjukkan oleh praktek-praktek penguasaan lahan, penggunaan tanah, pola nafkah warga setempat. Demikian juga dengan redistribusi manfaat yang diberikatan oleh pihak pemanfaat, bagi warga yang masih dapat mengakses lahan (menggarap) relatif lebih sejahtera dengan warga yang kehilangan garapan dan kini menjadi buruh tani. Implikasinya dari perubahan-perubahan ini adalah meningkatkan 'nilai tanah' bagi pemodal dan 'memarginalkan' warga setempat. Hal ini berkaitan dengan konsekuensi yang akan dihadapi di masa yang akan datang mengingat kondisi 'sulit' yang mereka alami saat ini, walaupun warga masih akses terhadap sumberdaya agraria.

Ketidak-adilan agraria yang terjadi di Mulyaharja menguntungkan pihak pemodal (khususnya), pemerintah (program berjalan lancar) dalam derajat yang sangat tinggi di satu sisi. Di sisi lain menguntungkan warga yang sama sekali tidak bekerja karena mendapat pekerjaan di sektor informal karena adanya perumahan PT dalam derajat yang 'kecil'. Selanjutnya, proses konversi (praktek-praktek pra-konversi, konversi dan pasca konversi) dipandang merugikan pihak masyarakat karena secara khusus, pasca konversi di Mulyaharja 'memarginalkan' dan 'mensubordinasikan' masyarakat setempat (khususnya petani dan buruh tani). Mereka telah kehilangan tanah garapan sekaligus kehilangan sumber penghasilan keluarganya. Implikasi lain dari sempitnya tanah adalah pergeseran tenaga kerja wanita dari sektor pertanian ke non-pertanian.

Berdasarkan fakta ketidak-adilan agraria di Kelurahan Mulyaharja dapat dirumuskan beberapa strategi mengurangi ketidak-adilan agraria yaitu: (1) melakukan penguatan kelembagaan lokal khususnya yang terkait langsung dengan 'pemilikan dan penguasaan sumberdaya agraria (tanah), dan (2) merumuskan praktek-praktek redistribusi manfaat bagi warga yang kini tidak mendapatkan tanah garapan misalnya dengan membuat batas maksimum tanah garapan untuk suatu keluarga dan meningkatkan upah warga yang bekerja bagi PT B dan PT C.

\section{Kesimpulan dan Saran}

\subsection{Kesimpulan}

Beberapa butir pokok yang dapat disimpulkan dari studi dan analisis kajian "konversi lahan pertanian dan perubahan struktur agraria" adalah: 
1. Faktor-faktor yang menyebabkan konversi lahan di Kelurahan Mulyaharja dapat dibagi dua yaitu (1) aras makro yang terdiri dari kebijakan pemerintah yang memberikan iklim kondusif bagi transformasi peruntukan suatu kawasan dan pertumbuhan penduduk alamiah dan non-alamiah (migrasi masuk lebih tinggi dari migrasi keluar) dan (2) aras mikro yang terdiri dari 'keterdesakan ekonomi', investasi pihak 'pemodal', proses alih hak milik atas tanah, dan proses pengadaan tanah.

2. Berdasarkan faktor-faktor penggerak utama konversi lahan serta dilengkapi dengan pihak pelaku, pemanfaat konversi dan proses konversi dilakukan, maka tipologi konversi yang terjadi di Kelurahan Mulyaharja dibagi menjadi 7 (tujuh) tipologi/pola yaitu: (1) konversi gradual-berpola sporadis, (2) konversi sistematik berpola 'enclave', (3) konversi sebagai respon atas pertumbuhan penduduk (population growth driven land conversion), konversi yang disebabkan oleh masalah sosial (social problem driven land conversion), konversi "tanpa beban", konversi adaptasi agraris, konversi multi bentuk atau tanpa pola. Pola konversi yang umum di kelurahan mulyaharja adalah konversi sistematik berpola 'enclave' dan pola konversi yang unik atau spesifik lokal adalah konversi masalah sosial (social problem driven land conversion) dan konversi adaptasi agraris.

3. Konversi lahan pertanian berimplikasi pada perubahan atau struktur agraria yang menghasilkan ketimpangan struktur agraria lahan terhadap kehidupan masyarakat menyangkut perubahan pola penguasaan lahan, pola nafkah dan hubungan pola produksi. Konversi Lahan yang terjadi di Kelurahan Mulyaharja umumnya lebih merupakan kehendak PT yang ingin menguasai lahan dan dapat digunakan untuk berbagai kepentingan. Pola nafkah, khususnya pada generasi yang muda sudah beralih ke sektor industri, dalam hal ini usaha 'bengkel'.

4. Ketimpangan struktur agraria berimplikasi terhadap kehidupan/kesejahteraan masyarakat. Melalui konversi lahan, perubahan hak atas atah jelas telah berubah dan juga secara perlahan merubah budaya 'bertani' khususunya pada generasi muda. Generasi muda lebih senang bekerja di luar sektor pertanian, yaitu usaha 'bengkel' sendal dan sepatu.

5. Implikasi teoritis dari studi ini adalah perubahan struktur agraria karena proses konversi lahan dapat 'dibangun tesis keadilan agraria' yang berintikan gagasan tentang perubahan struktur agraria yang menyebabkan tekanan sosial yang tidak merata, dimana kaum berpendapatan rendah/miskin adalah penderita utama atas hadirnya perubahan tersebut. Selanjutnya, ketidak-adilan agraria dimaknai sebagai suatu keadaan dimana proses konversi (praktek-praktek pra-konversi, konversi dan pasca konversi) dipandang merugikan pihak masyarakat (pelaku konversi) karena secara khusus, pasca konversi di Mulyaharja 'memarginalkan' dan 'mensubordinasikan' masyarakat setempat (khususnya petani dan buruh tani). Sementara keadilan agraria adalah kondisi dimana praktek-praktek pemanfaatan sumberdaya agraria oleh subyek agraria (pelaku konversi dan pemanfaat konversi) khususnya setelah alih hak milik (dari pelaku kepada pemanfaat) menyangkut redistribusi manfaat atau redistribusi penghasilan 
dari pemanfaat konversi kepada pelaku) yang dapat meningkatkan derajat kesejahteraan pemanfaat pelaku konversi Tesis ini juga 'dibangun' dari fakta-fakta ketidak-adilan agraria di Kelurahan Mulyaharja. Harapan ke depan adalah proses pembangunan yang memperhatikan 'keadilan agraria' (pembangunan agraria yang memihak pada kaum miskin).

\subsection{Saran}

Salah satu saran konkrit dari hasil penelitian ini adalah perlu upaya dari seluruh stakeholders yang akses maupun yang belum akses untuk meminimalkan laju konversi lahan. Hal ini ditunjukkan praktek-praktek ketidak-adilan di Kelurahan Mulyaharja. Untuk itu, dari hasil kajian dapat disarankan langkah strategi mengurangi ketidakadilan agraria yaitu: (1) melakukan penguatan kelembagaan lokal khususnya yang terkait langsung dengan 'pemilikan dan penguasaan' sumberdaya agraria (tanah), dan merumuskan praktek-praktek redistribusi manfaat bagi warga yang kini tidak mendapatkan tanah garapan misalnya dengan membuat batas maksimum tanah garapan untuk suatu keluarga dan meningkatkan upah warga yang bekerja bagi perumahan PT B dan PT C.

\section{Daftar Pustaka}

Neuman, W.L. 1994. Social Research Method: Qualitative and Quantitative Approach (2 nd Edition). Allyn and Bacon Sydney.

Scheltema.1985. Bagi Hasil di Hindia Belanda. Yayasan Obor Indonesia. Jakarta.

Wiradi, G. dan Makali. 1984. Penguasaan Tanah dan Kelembagaan dalam F. Kasryno (Ed.), Prospek Pembangunan Ekonomi Pedesaan Indonesia. Yayasan Obor Indonesia. Jakarta.

Yin, R.K. 1996. Studi Kasus: Desain dan Metode. Raja Grafindo Persada. 
270 | Sihaloho, M. et al. Konversi Lahan Pertanian dan Perubahan Struktur Agraria 